\title{
Supplement
}

\section{Projected impacts of climate change on hydropower potential in China}

\author{
Xingcai Liu ${ }^{1}$, Qiuhong Tang ${ }^{1}$, Nathalie Voisin ${ }^{2}$, Huijuan $\mathrm{Cui}^{3}$ \\ ${ }^{1}$ Key Laboratory of Water Cycle and Related Land Surface Processes, Institute of Geographical Sciences and \\ Natural Resources Research, Chinese Academy of Sciences, A11, Datun Road, Chaoyang District, Beijing, \\ China. \\ ${ }^{2}$ Pacific Northwest National Laboratory, 1100 N Dexter Ave, Seattle, WA, USA. \\ ${ }^{3}$ Key Laboratory of Land Surface Pattern and Simulation, Institute of Geographical Sciences and Natural \\ Resources Research, Chinese Academy of Sciences, 11A Datun Road, Chaoyang District, Beijing, China. \\ Correspondence to: Qiuhong Tang (tangqh@igsnrr.ac.cn)
}




\section{Tables}

Table S1. Main characteristics of the GHMs used in this study, based on Schewe et al. (2014).......... 3

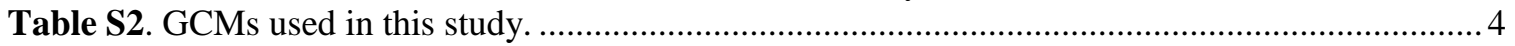

Table S3. Sensitivity tests for parameters of DHP calculation (see Equation 1) ..................................5

Table S4. Estimates of annual and seasonal GHP (GW) for regions and China over 1971-2000_........ 6

Table S5. Percentiles of relative annual GHP changes (\%) of China over 2020-2050 across GHMs

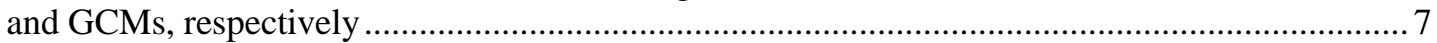

Table S6. Percentiles of relative annual GHP changes (\%) of China over 2070-2099 across GHMs

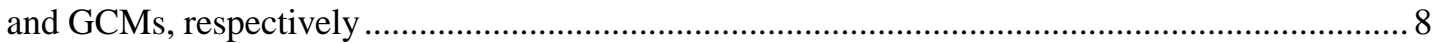

Table S7. Percentiles of relative seasonal GHP changes (\%) of China over 2020-2050 (2035) and 2070-2099 (2085) across the ensemble of GCM-GHM combinations. ....................................... 9

Table S8. Percentiles of relative annual DHP changes (\%) of China over 2020-2050 across GHMs and GCMs, respectively

Table S9. Percentiles of relative annual DHP changes (\%) of China over 2070-2099 across GHMs and GCMs, respectively

Table S10. Percentiles of annual DHP changes (\%) for regions in China over 2020-2050 (2035) and 2070-2099 (2085) across the ensemble of GCM-GHM combinations. 
Table S1. Main characteristics of the GHMs used in this study, based on Schewe et al. (2014).

\begin{tabular}{|c|c|c|c|c|c|c|c|c|c|}
\hline Model name & $\begin{array}{l}\text { Time } \\
\text { step } \\
\text { length }\end{array}$ & $\begin{array}{l}\text { Meteorological } \\
\text { forcing } *\end{array}$ & $\begin{array}{l}\text { Energy } \\
\text { balance }\end{array}$ & $\begin{array}{l}\text { Evaporatio } \\
\text { n scheme }\end{array}$ & Runoff scheme & Snow scheme & $\begin{array}{l}\text { Vegetation } \\
\text { dynamics }\end{array}$ & $\begin{array}{l}\mathrm{CO}_{2} \\
\text { effect }\end{array}$ & References \\
\hline $\mathrm{DBH}$ & $1 \mathrm{hr}$ & $\begin{array}{l}\mathrm{P}, \mathrm{T}, \mathrm{W}, \mathrm{Q}, \mathrm{LW}, \\
\mathrm{SW}, \mathrm{SP}\end{array}$ & Yes & $\begin{array}{l}\text { Energy } \\
\text { balance }\end{array}$ & Infiltration excess & Energy balance & No & Constant & $\begin{array}{l}\text { Tang et al. } \\
(2007)\end{array}$ \\
\hline H08 & Daily & $\begin{array}{l}\text { R, S, T, W, Q, } \\
\text { LW, SW, SP }\end{array}$ & Yes & $\begin{array}{l}\text { Bulk } \\
\text { formula }\end{array}$ & $\begin{array}{l}\text { Saturation excess, non- } \\
\text { linear }\end{array}$ & Energy balance & No & No & $\begin{array}{l}\text { Hanasaki et } \\
\text { al. (2008) }\end{array}$ \\
\hline Mac-PDM.09 & Daily & $\begin{array}{l}\mathrm{P}, \mathrm{T}, \mathrm{W}, \mathrm{Q}, \mathrm{LWn}, \\
\text { SW }\end{array}$ & No & $\begin{array}{l}\text { Penman- } \\
\text { Monteith }\end{array}$ & $\begin{array}{l}\text { Saturation excess, non- } \\
\text { linear }\end{array}$ & Degree-day & No & No & $\begin{array}{l}\text { Gosling and } \\
\text { Arnell } \\
(2011)\end{array}$ \\
\hline MATSIRO & $1 \mathrm{hr}$ & $\begin{array}{l}\text { R, S, T, W, Q, } \\
\text { LW, SW, SP }\end{array}$ & Yes & $\begin{array}{l}\text { Bulk } \\
\text { formula }\end{array}$ & $\begin{array}{l}\text { Infiltration excess, } \\
\text { saturation excess, } \\
\text { groundwater. }\end{array}$ & Energy balance & No & Constant & $\begin{array}{l}\text { Takata et al. } \\
(2003)\end{array}$ \\
\hline MPI-HM & Daily & $\begin{array}{l}\text { P, T, W, Q, LWn, } \\
\text { SW, SP }\end{array}$ & No & $\begin{array}{l}\text { Penman- } \\
\text { Monteith }\end{array}$ & $\begin{array}{l}\text { Saturation excess, non- } \\
\text { linear }\end{array}$ & Degree-day & No & No & $\begin{array}{l}\text { Hagemann } \\
\text { and Gates } \\
(2003)\end{array}$ \\
\hline PCR-GLOBWB & Daily & $\mathrm{P}, \mathrm{T}$ & No & Hamon & $\begin{array}{l}\text { Saturation Excess Beta } \\
\text { Function }\end{array}$ & Degree Day & No & No & $\begin{array}{l}\text { van Beek et } \\
\text { al. }(2011)\end{array}$ \\
\hline VIC & $\begin{array}{l}\text { Daily, } \\
\text { 3hr snow }\end{array}$ & $\begin{array}{l}\text { P, T, W, Q, LW, } \\
\text { SW, SP. }\end{array}$ & $\begin{array}{l}\text { Only for } \\
\text { snow. }\end{array}$ & $\begin{array}{l}\text { Penman- } \\
\text { Monteith }\end{array}$ & $\begin{array}{l}\text { Saturation excess, non- } \\
\text { linear }\end{array}$ & Energy balance. & No & No & $\begin{array}{l}\text { Liang et al. } \\
\text { (1994) }\end{array}$ \\
\hline WBM & Daily & $\mathrm{P}, \mathrm{T}$ & No & Hamon & Saturation Excess & Empirical formula & No & No & $\begin{array}{l}\text { Wisser et al. } \\
(2010)\end{array}$ \\
\hline
\end{tabular}

* P: precipitation, T: temperature, W: wind speed, Q: air specific humidity, LW: downwelling longwave, SW: downwelling shortwave, SP: surface pressure. 
Table S2. GCMs used in this study.

\begin{tabular}{|l|l|l|}
\hline GCM & Institution & Description \\
\hline GFDL-ESM2M & Geophysical Fluid Dynamics Laboratory & Dunne, et al. (2012) \\
\hline HadGEM2-ES & Met Office Hadley Centre, UK & Jones, et al. (2011) \\
\hline IPSL-CM5A-LR & Institut Pierre-Simon Laplace Climate Modelling Centre & Dufresne et al. (2013) \\
\hline MIROC-ESM-CHEM & $\begin{array}{l}\text { Japan Agency for Marine-Earth Science and Technology, the Atmosphere and Ocean Research } \\
\text { Institute at the University of Tokyo, and the National Institute for Environmental Studies }\end{array}$ & Watanabe, et al., (2011) \\
\hline NorESM1-M & Norwegian Climate Centre & Bentsen et al. (2013) \\
\hline
\end{tabular}


Table S3. Sensitivity tests for parameters of DHP calculation (see Equation 1).

\begin{tabular}{|c|c|}
\hline Parameter & Values \\
\hline$\alpha$ & $0.65,0.75, \mathbf{0 . 8 5}, 0.95$ \\
\hline$\beta$ & $1,2,3$ \\
\hline$K_{c}$ & $0.4, \mathbf{0 . 5}, 0.6$ \\
\hline IHC & $0.9 * \mathrm{IHC}, \mathbf{I H C}, 1.1 * \mathrm{IHC}$ \\
\hline
\end{tabular}


Table S4. Estimates of annual and seasonal GHP (GW) for regions and China over 1971-2000.

\begin{tabular}{|l|c|c|c|c|}
\hline GHM Percentile & $50^{\text {th }}$ & $25^{\text {th }}$ & $75^{\text {th }}$ & IQR \\
\hline GFDL-ESM2M & 720 & 510 & 743 & 234 \\
\hline HadGEM2-ES & 676 & 482 & 710 & 228 \\
\hline IPSL-CM5A-LR & 662 & 490 & 690 & 200 \\
\hline MIROC-ESM-CHEM & 715 & 506 & 734 & 228 \\
\hline NorESM1-M & 704 & 487 & 755 & 268 \\
\hline \multicolumn{5}{|l|}{} \\
\hline Region & 25 & 11 & 32 & 21 \\
\hline NC & 11 & 9 & 14 & 5 \\
\hline NEC & 29 & 26 & 31 & 5 \\
\hline EC & 91 & 79 & 100 & 21 \\
\hline SCC & 440 & 356 & 488 & 132 \\
\hline SWC & 62 & 40 & 74 & 34 \\
\hline NWC & \multicolumn{5}{|l}{} \\
\hline \multicolumn{5}{|l|l|}{} \\
\hline Season & 314 & 280 & 385 & 105 \\
\hline MAM & 1116 & 941 & 1218 & 278 \\
\hline JJA & 852 & 662 & 914 & 252 \\
\hline SON & 189 & 125 & 270 & 146 \\
\hline DJF &
\end{tabular}


Table S5. Percentiles of relative annual GHP changes (\%) of China over 2020-2050 across GHMs and GCMs, respectively

\begin{tabular}{|c|c|c|c|c|c|c|}
\hline Percentile & \multicolumn{3}{|c|}{ RCP2.6 } & \multicolumn{3}{|c|}{ RCP8.5 } \\
\hline GHM & $50^{\text {th }}$ & $25^{\text {th }}$ & $75^{\text {th }}$ & $50^{\text {th }}$ & $25^{\text {th }}$ & $75^{\text {th }}$ \\
\hline DBH & 4.73 & 1.50 & 5.37 & 1.73 & 0.37 & 4.93 \\
\hline H08 & 4.13 & 1.03 & 5.00 & 0.91 & -0.48 & 1.94 \\
\hline Mac-PDM.09 & 1.89 & 0.40 & 4.83 & 0.24 & -2.97 & 1.12 \\
\hline MATSIRO & 1.06 & -4.43 & 2.34 & -5.77 & -7.44 & 19.82 \\
\hline MPI-HM & 4.49 & -2.08 & 5.02 & -2.74 & -3.81 & -0.45 \\
\hline PCR-GLOBWB & 4.17 & 2.35 & 4.76 & 1.36 & -0.45 & 3.66 \\
\hline VIC & -1.38 & -3.81 & 1.74 & -3.95 & -6.96 & -2.15 \\
\hline WBM & -0.16 & -3.90 & 2.93 & -4.77 & -8.03 & -2.61 \\
\hline \multicolumn{7}{|l|}{ GCM } \\
\hline GFDL-ESM2M & 4.37 & 2.52 & 4.88 & -0.97 & -3.22 & 0.93 \\
\hline HadGEM2-ES & -5.20 & -9.05 & -1.80 & -5.83 & -9.79 & -2.66 \\
\hline IPSL-CM5A-LR & 4.89 & 3.28 & 5.75 & 2.66 & -0.69 & 4.40 \\
\hline MIROC-ESM-CHEM & 0.61 & -2.13 & 3.20 & 0.87 & -3.42 & 3.72 \\
\hline NorESM1-M & 2.16 & 0.87 & 3.81 & -1.75 & -6.03 & 0.27 \\
\hline All & 2.22 & -1.21 & 4.58 & -1.71 & -4.36 & 1.41 \\
\hline
\end{tabular}


Table S6. Percentiles of relative annual GHP changes (\%) of China over 2070-2099 across GHMs and GCMs, respectively

\begin{tabular}{|c|c|c|c|c|c|c|}
\hline Percentile & \multicolumn{3}{|c|}{$\mathrm{RCP} 2.6$} & \multicolumn{3}{|c|}{ RCP8.5 } \\
\hline GHM & $50^{\text {th }}$ & $25^{\text {th }}$ & $75^{\text {th }}$ & $50^{\text {th }}$ & $25^{\text {th }}$ & $75^{\text {th }}$ \\
\hline DBH & 5.18 & 2.31 & 9.45 & 13.11 & 9.86 & 23.04 \\
\hline $\mathrm{H} 08$ & 4.25 & 0.62 & 6.22 & 7.03 & 5.80 & 10.58 \\
\hline Mac-PDM.09 & 3.65 & 1.37 & 5.12 & 5.97 & 1.66 & 13.00 \\
\hline MATSIRO & 0.92 & -3.90 & 326.27 & -6.08 & -7.35 & 19.02 \\
\hline MPI-HM & 1.07 & -2.32 & 5.81 & 4.84 & 2.90 & 11.50 \\
\hline PCR-GLOBWB & 6.85 & 3.24 & 8.15 & 8.62 & 7.51 & 15.66 \\
\hline VIC & -2.10 & -3.30 & 0.27 & -5.31 & -7.24 & 2.79 \\
\hline WBM & 1.74 & -0.69 & 4.82 & -1.94 & -7.11 & 4.57 \\
\hline \multicolumn{7}{|l|}{ GCM } \\
\hline GFDL-ESM2M & -1.53 & -4.09 & -0.20 & 5.38 & -0.55 & 7.81 \\
\hline HadGEM2-ES & 2.80 & -0.52 & 5.72 & -1.34 & -10.01 & 4.62 \\
\hline IPSL-CM5A-LR & 1.50 & -0.77 & 3.55 & 7.42 & -0.88 & 12.29 \\
\hline MIROC-ESM-CHEM & 8.86 & 6.71 & 10.03 & 20.63 & 13.99 & 26.56 \\
\hline NorESM1-M & 4.44 & 2.28 & 5.27 & 3.51 & -5.71 & 7.60 \\
\hline All & 2.93 & -0.53 & 6.71 & 6.27 & -2.36 & 10.57 \\
\hline
\end{tabular}


Table S7. Percentiles of relative seasonal GHP changes (\%) of China over 2020-2050 (2035) and 20702099 (2085) across the ensemble of GCM-GHM combinations.

\begin{tabular}{|c|c|c|c|c|c|c|}
\hline \multirow{2}{*}{ Season $\quad$ Percentile } & \multicolumn{3}{|c|}{ RCP2.6 } & \multicolumn{3}{|c|}{ RCP8.5 } \\
\hline & $50^{\text {th }}$ & $25^{\text {th }}$ & $75^{\text {th }}$ & $50^{\text {th }}$ & $25^{\text {th }}$ & $75^{\text {th }}$ \\
\hline \multicolumn{7}{|l|}{2035} \\
\hline MAM & 0.43 & -2.29 & 2.39 & -1.43 & -5.87 & 0.75 \\
\hline JJA & 0.38 & -2.87 & 3.78 & -2.31 & -7.50 & -0.60 \\
\hline $\mathrm{SON}$ & 3.86 & -0.17 & 8.14 & 1.68 & -2.27 & 6.06 \\
\hline DJF & 1.36 & -3.98 & 7.73 & -0.57 & -3.53 & 5.63 \\
\hline \multicolumn{7}{|l|}{2085} \\
\hline MAM & -0.77 & -5.54 & 2.36 & -0.06 & -9.78 & 6.84 \\
\hline JJA & 1.49 & -1.46 & 4.39 & 6.86 & -4.48 & 14.13 \\
\hline SON & 7.46 & 0.28 & 10.82 & 7.88 & 2.79 & 17.46 \\
\hline DJF & 3.62 & -3.88 & 11.35 & 2.51 & -7.82 & 11.40 \\
\hline
\end{tabular}


Table S8. Percentiles of relative annual DHP changes (\%) of China over 2020-2050 across GHMs and GCMs, respectively

\begin{tabular}{|c|c|c|c|c|c|c|}
\hline Percentile & \multicolumn{3}{|c|}{ RCP2.6 } & \multicolumn{3}{|c|}{ RCP8.5 } \\
\hline GHM & $50^{\text {th }}$ & $25^{\text {th }}$ & $75^{\text {th }}$ & $50^{\text {th }}$ & $25^{\text {th }}$ & $75^{\text {th }}$ \\
\hline DBH & 0.32 & -0.93 & 3.21 & -1.30 & -3.23 & 2.27 \\
\hline H08 & -0.86 & -5.04 & 0.89 & -4.51 & -7.61 & -0.13 \\
\hline Mac-PDM.09 & -0.42 & -4.39 & 1.12 & -5.41 & -6.34 & -1.08 \\
\hline MATSIRO & -2.70 & -7.10 & 18.37 & -7.65 & -11.92 & -4.02 \\
\hline MPI-HM & -2.86 & -7.54 & -0.93 & -9.41 & -10.82 & -3.20 \\
\hline PCR-GLOBWB & -1.22 & -4.23 & 0.96 & -5.47 & -6.07 & -1.05 \\
\hline VIC & -4.99 & -8.59 & -1.90 & -5.64 & -8.75 & -1.47 \\
\hline WBM & -4.43 & -8.78 & -1.69 & -10.64 & -12.83 & -6.47 \\
\hline \multicolumn{7}{|l|}{ GCM } \\
\hline GFDL-ESM2M & -2.41 & -3.85 & -1.04 & -6.62 & -10.03 & -4.99 \\
\hline HadGEM2-ES & -0.29 & -2.45 & 0.32 & -1.37 & -3.63 & -0.63 \\
\hline IPSL-CM5A-LR & -4.36 & -5.76 & -2.32 & -7.70 & -11.32 & -5.79 \\
\hline MIROC-ESM-CHEM & -6.66 & -10.39 & -3.18 & -8.59 & -11.22 & -5.98 \\
\hline NorESM1-M & 2.80 & 1.63 & 3.19 & -1.28 & -3.27 & -0.08 \\
\hline All & -2.22 & -4.91 & 0.33 & -5.44 & -8.95 & -1.46 \\
\hline
\end{tabular}


Table S9. Percentiles of relative annual DHP changes (\%) of China over 2070-2099 across GHMs and GCMs, respectively

\begin{tabular}{|c|c|c|c|c|c|c|}
\hline Percentile & \multicolumn{3}{|c|}{ RCP2.6 } & \multicolumn{3}{|c|}{ RCP8.5 } \\
\hline GHM & $50^{\text {th }}$ & $25^{\text {th }}$ & $75^{\text {th }}$ & $50^{\text {th }}$ & $25^{\text {th }}$ & $75^{\text {th }}$ \\
\hline DBH & 3.72 & -1.50 & 5.57 & 7.51 & -1.34 & 8.04 \\
\hline H08 & -0.98 & -5.06 & 2.23 & -2.82 & -9.83 & 0.05 \\
\hline Mac-PDM.09 & 1.93 & -3.50 & 3.25 & -0.91 & -7.35 & 2.14 \\
\hline MATSIRO & -1.19 & -5.97 & 16.13 & -8.78 & -20.93 & 8.77 \\
\hline MPI-HM & -1.33 & -8.58 & 0.20 & -4.45 & -15.09 & -3.47 \\
\hline PCR-GLOBWB & 2.63 & -3.49 & 4.63 & 1.16 & -8.39 & 1.88 \\
\hline VIC & -5.60 & -9.70 & -1.11 & -4.35 & -12.41 & -2.96 \\
\hline WBM & 1.49 & -6.66 & 3.98 & -6.26 & -16.74 & -4.81 \\
\hline \multirow{2}{*}{\multicolumn{7}{|c|}{ GCM }} \\
\hline & & & & & & \\
\hline GFDL-ESM2M & -5.11 & -7.03 & -2.53 & -9.24 & -13.67 & -5.16 \\
\hline HadGEM2-ES & 3.44 & 0.70 & 6.13 & 0.17 & -2.56 & 2.12 \\
\hline IPSL-CM5A-LR & -5.75 & -8.44 & -2.61 & -16.75 & -22.63 & -11.77 \\
\hline MIROC-ESM-CHEM & -1.15 & -2.59 & 2.06 & -3.22 & -4.67 & 4.33 \\
\hline NorESM1-M & 2.50 & -0.52 & 3.70 & -2.63 & -5.36 & 0.69 \\
\hline All & -1.08 & -4.87 & 2.71 & -3.68 & -10.23 & 0.38 \\
\hline
\end{tabular}


Table S10. Percentiles of annual DHP changes (\%) for regions in China over 2020-2050 (2035) and 20702099 (2085) across the ensemble of GCM-GHM combinations.

\begin{tabular}{|c|c|c|c|c|c|c|}
\hline \multirow{2}{*}{ Season } & \multicolumn{3}{|c|}{ RCP2.6 } & \multicolumn{3}{|c|}{ RCP8.5 } \\
\hline & $50^{\text {th }}$ & $25^{\text {th }}$ & $75^{\text {th }}$ & $50^{\text {th }}$ & $25^{\text {th }}$ & $75^{\text {th }}$ \\
\hline \multicolumn{7}{|l|}{2035} \\
\hline North & 7.03 & 2.65 & 11.56 & 1.42 & -3.73 & 12.48 \\
\hline Northeast & 2.15 & -2.83 & 9.19 & -2.83 & -11.02 & 3.08 \\
\hline East & 1.89 & -11.18 & 3.10 & -7.57 & -11.69 & -0.83 \\
\hline South Central & -3.26 & -5.51 & -0.42 & -5.39 & -9.11 & -2.78 \\
\hline Northwest & -2.78 & -4.98 & 1.47 & -5.42 & -7.00 & -0.92 \\
\hline Southwest & -3.41 & -9.08 & 1.75 & -4.56 & -13.23 & 0.25 \\
\hline Hotspot 2 & -2.55 & -4.92 & -0.43 & -5.72 & -8.41 & -3.03 \\
\hline China & -2.22 & -4.91 & 0.33 & -5.44 & -8.95 & -1.46 \\
\hline \multicolumn{7}{|l|}{2085} \\
\hline North & 3.52 & -1.84 & 12.56 & 7.18 & -0.20 & 15.44 \\
\hline Northeast & 0.40 & -6.12 & 9.37 & -1.84 & -13.02 & 15.03 \\
\hline East & -2.35 & -7.29 & 3.23 & -7.07 & -11.81 & 2.60 \\
\hline South Central & -1.07 & -4.49 & 2.70 & -3.77 & -9.75 & 0.59 \\
\hline Northwest & 0.14 & -3.65 & 3.95 & -3.41 & -8.57 & 1.86 \\
\hline Southwest & 1.64 & -4.65 & 4.52 & -0.48 & -14.96 & 9.77 \\
\hline Hotspot 2 & -0.82 & -3.61 & 2.90 & -5.01 & -9.60 & 1.13 \\
\hline China & -1.25 & -4.93 & 2.57 & -3.85 & -10.47 & 0.24 \\
\hline
\end{tabular}




\section{Reference}

Bentsen, M., et al., 2013: The Norwegian Earth System Model, NorESM1-M - Part 1: Description and basic evaluation of the physical climate. Geosci. Model Dev., 6 (3), 687-720.

Dufresne, J. L., et al., 2013: Climate change projections using the IPSL-CM5 Earth System Model: from CMIP3 to CMIP5. Clim. Dyn., 40 (9-10), 2123-2165.

Gosling, S. N., and N. W. Arnell, 2011: Simulating current global river runoff with a global hydrological model: model revisions, validation, and sensitivity analysis. Hydrol. Processes, 25 (7), 1129-1145. Hagemann, S., and L. D. Gates, 2003: Improving a subgrid runoff parameterization scheme for climate models by the use of high resolution data derived from satellite observations. Clim. Dyn., 21 (3-4), 349359.

Hanasaki, N., S. Kanae, T. Oki, K. Masuda, K. Motoya, N. Shirakawa, Y. Shen, and K. Tanaka, 2008: An integrated model for the assessment of global water resources - Part 1: Model description and input meteorological forcing. Hydrol. Earth Syst. Sci., 12 (4), 1007-1025.

Dunne, John P., et al., 2012: GFDL's ESM2 Global Coupled Climate-Carbon Earth System Models. Part I: Physical Formulation and Baseline Simulation Characteristics. J. Climate, 25, 6646-6665. doi: 10.1175/JCLI-D-11-00560.1.

Jones, C. D., et al., 2011: The HadGEM2-ES implementation of CMIP5 centennial simulations. Geosci. Model Dev., 4 (3), 543-570.

Liang, X., D. P. Lettenmaier, E. F. Wood, and S. J. Burges, 1994: A simple hydrologically based model of land surface water and energy fluxes for general circulation models. J. Geophys. Res., 99 (D7), 14415 14428.

Schewe, J., et al., 2014: Multimodel assessment of water scarcity under climate change. Proc. Nat. Acad. Sci. U.S.A., 111, 3245-3250.

Takata, K., S. Emori, and T. Watanabe, 2003: Development of the minimal advanced treatments of surface interaction and runoff. Global Planet. Change, 38 (1-2), 209-222.

Tang, Q., T. Oki, S. Kanae, and H. Hu, 2007: The influence of precipitation variability and partial irrigation within grid cells on a hydrological simulation. J. Hydrometeor, 8, 499-512.

van Beek, L. P. H., Y. Wada, and M. F. P. Bierkens, 2011: Global monthly water stress: 1. Water balance and water availability. Water Resour. Res., 47 (7), W07517.

Watanabe, S., et al., 2011: MIROC-ESM 2010: model description and basic results of CMIP5-20c3m experiments. Geosci. Model Dev., 4 (4), 845-872.

Wisser, D., B. M. Fekete, C. J. Vörösmarty, A. H. Schumann, 2010: Reconstructing 20th century global hydrography: a contribution to the Global Terrestrial Network- Hydrology (GTN-H). Hydrol. Earth Syst. Sci., 14 (1), 1-24. 


\section{Figures}

Figure S1. Medians of relative changes in the annual mean GHPs for 20202050 (a) and 20702099 (b) compared to the historical period (1971 2000) across the ensemble of GCM-GHM combinations under RCP2.6.

Figure S2. Medians of relative changes in annual discharge (without regulation) across the ensemble of GCM-GHM combinations for 20202050 (2035) and 20702099 (2085) compared to the historical period (1971 2000).

Figure S3. Medians of relative seasonal GHP changes for 20202050 (left) and 20702099 (right) under RCP8.5.

Figure S4. Agreements between relative GHP changes across the ensemble of GCM-GHM combinations calculated as the difference of positive and negative fractions of total ensemble. 18

Figure S5. Relative DHP changes for each reservoir for 20202050 (2035) and 20702099 (2085) under RCP2.6.

Figure S6. Relative DHP changes for regions of China for 20202050 (2035) and 20702099 (2085) under RCP2.6.

Figure S7. Relative changes in monthly GHPs (DHPs) and discharges (reservoir inflow) for hotspot regions for 20202050 (2035) and 20702099 (2085) under RCP2.6.

Figure S8. Medians of annual mean temperature changes in China in 2035 and 2085 compared to the historical period (1971 2000) across the five GCMs.

Figure S9. Medians of relative annual precipitation changes in China in 2035 and 2085 compared to

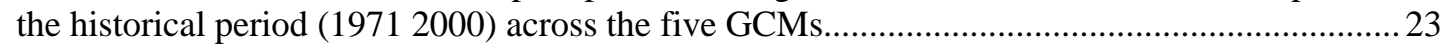

Figure S10. The ratio of GCM variance to total variance across all GCMs and GHMs....................... 24

Figure S11. Medians of relative changes in the DHPs of present reservoirs in China over the 2010-2084 period under RCP2.6 (a) and RCP8.5 (b) for different $\alpha$ values.

Figure S12. Medians of relative changes in the DHPs of present reservoirs in China over the 2010-2084 period under RCP2.6 (a) and RCP8.5 (b) for different $\beta$ values.....

Figure S13. Medians of relative changes in the DHPs of present reservoirs in China over the 2010-2084 period under RCP2.6 (a) and RCP8.5 (b) for different $K_{c}$ values.

Figure S14. Medians of relative changes in the DHPs of present reservoirs in China over the 2010-2084 period under RCP2.6 (a) and RCP8.5 (b) for different IHCs 


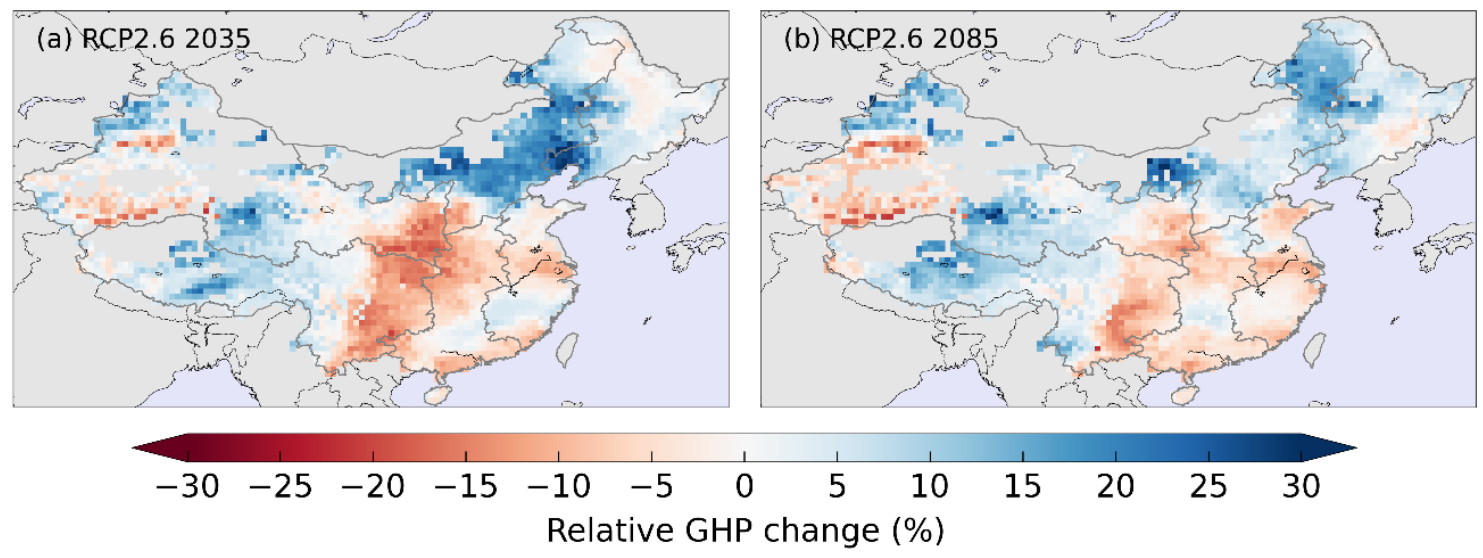

Figure S1. Medians of relative changes in the annual mean GHPs for 20202050 (a) and 20702099 (b) compared to the historical period (1971 2000) across the ensemble of GCM-GHM combinations under RCP2.6. 

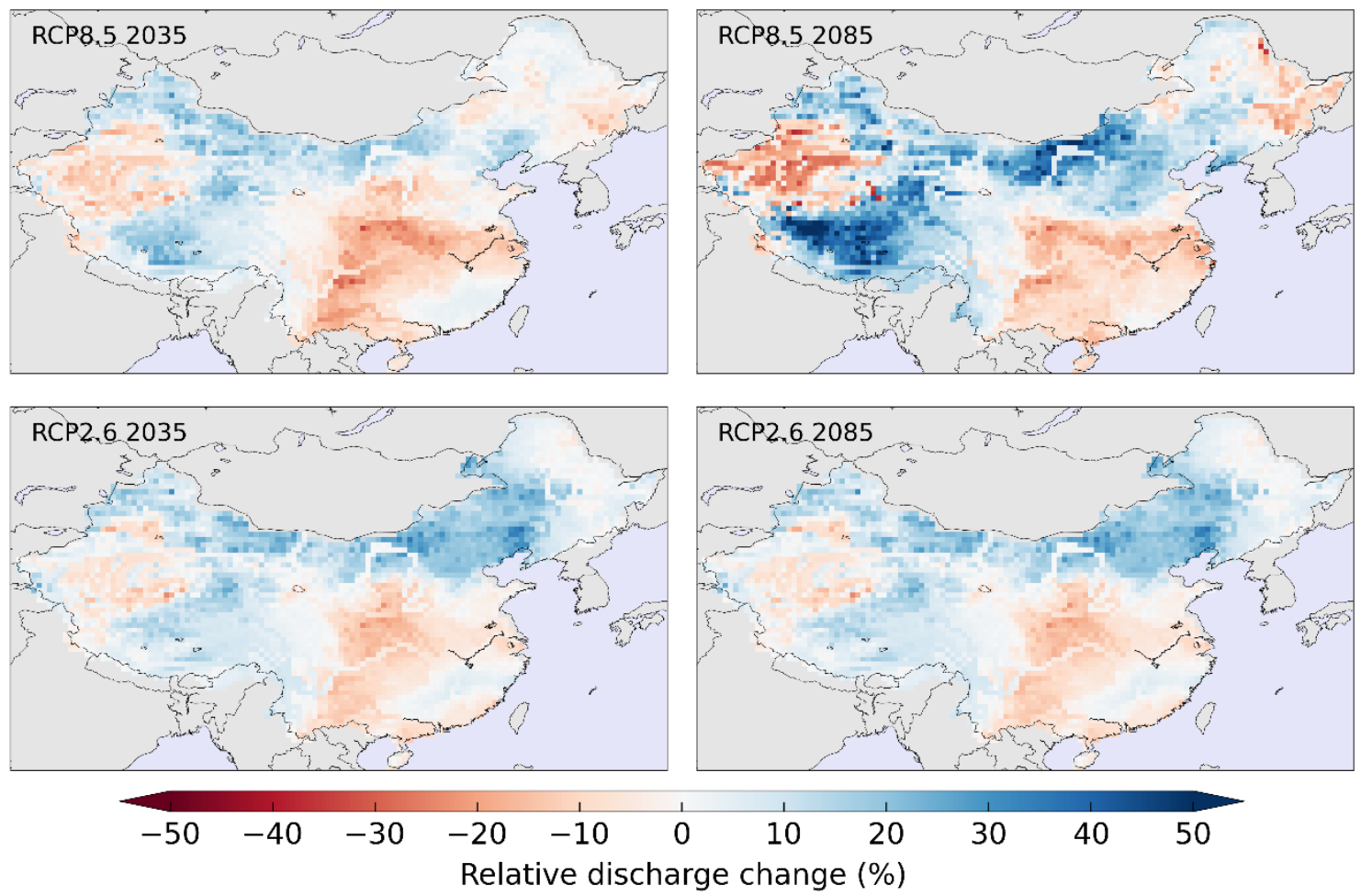

Figure S2. Medians of relative changes in annual discharge (without regulation) across the ensemble of GCM-GHM combinations for 20202050 (2035) and 20702099 (2085) compared to the historical period (1971 2000). 


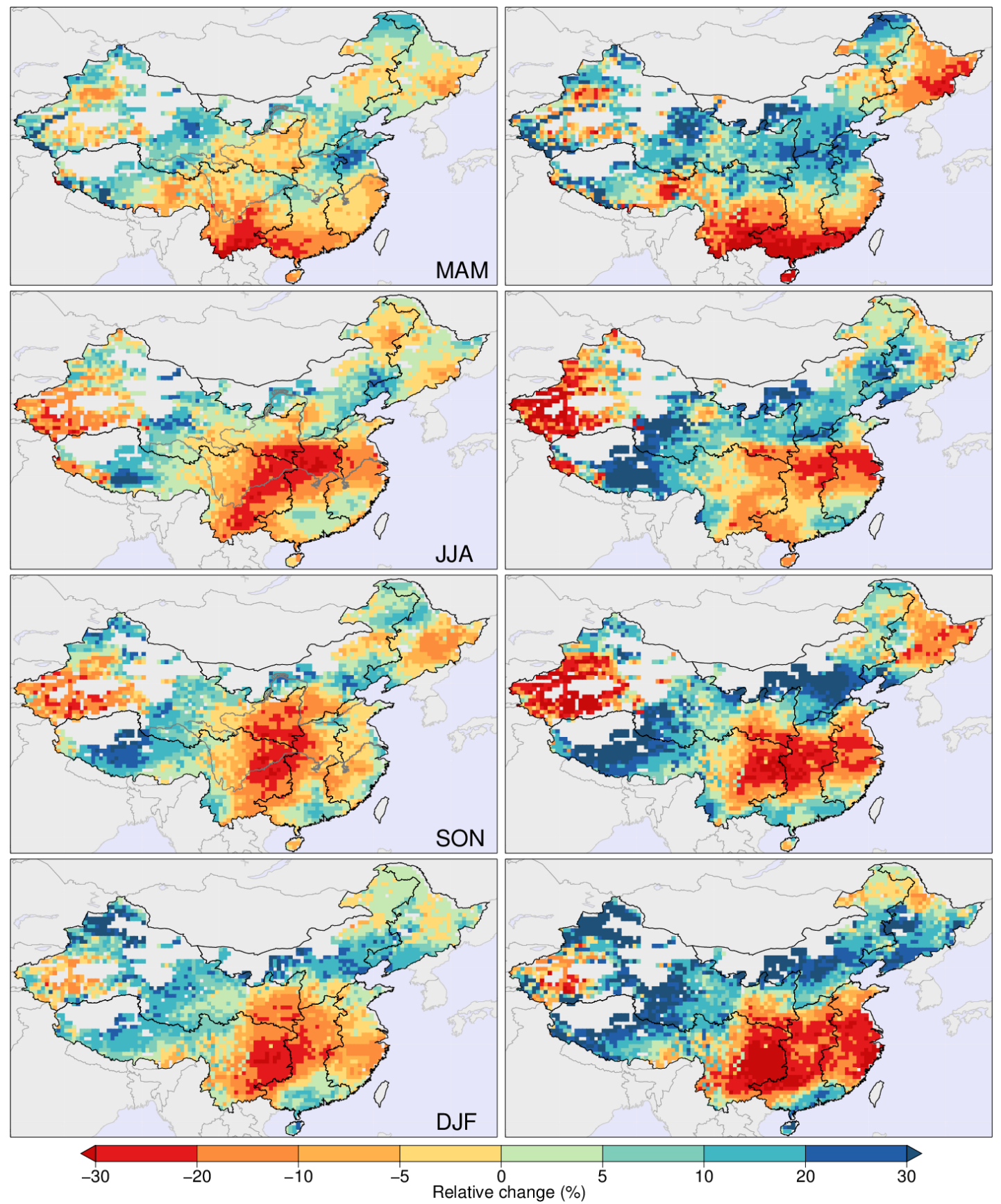

Figure S3. Medians of relative seasonal GHP changes for 20202050 (left) and 20702099 (right) under RCP8.5.

MAM: March, April, May; JJA: June, July, August; SON: September, October, November; DJF:

December, January, February. 

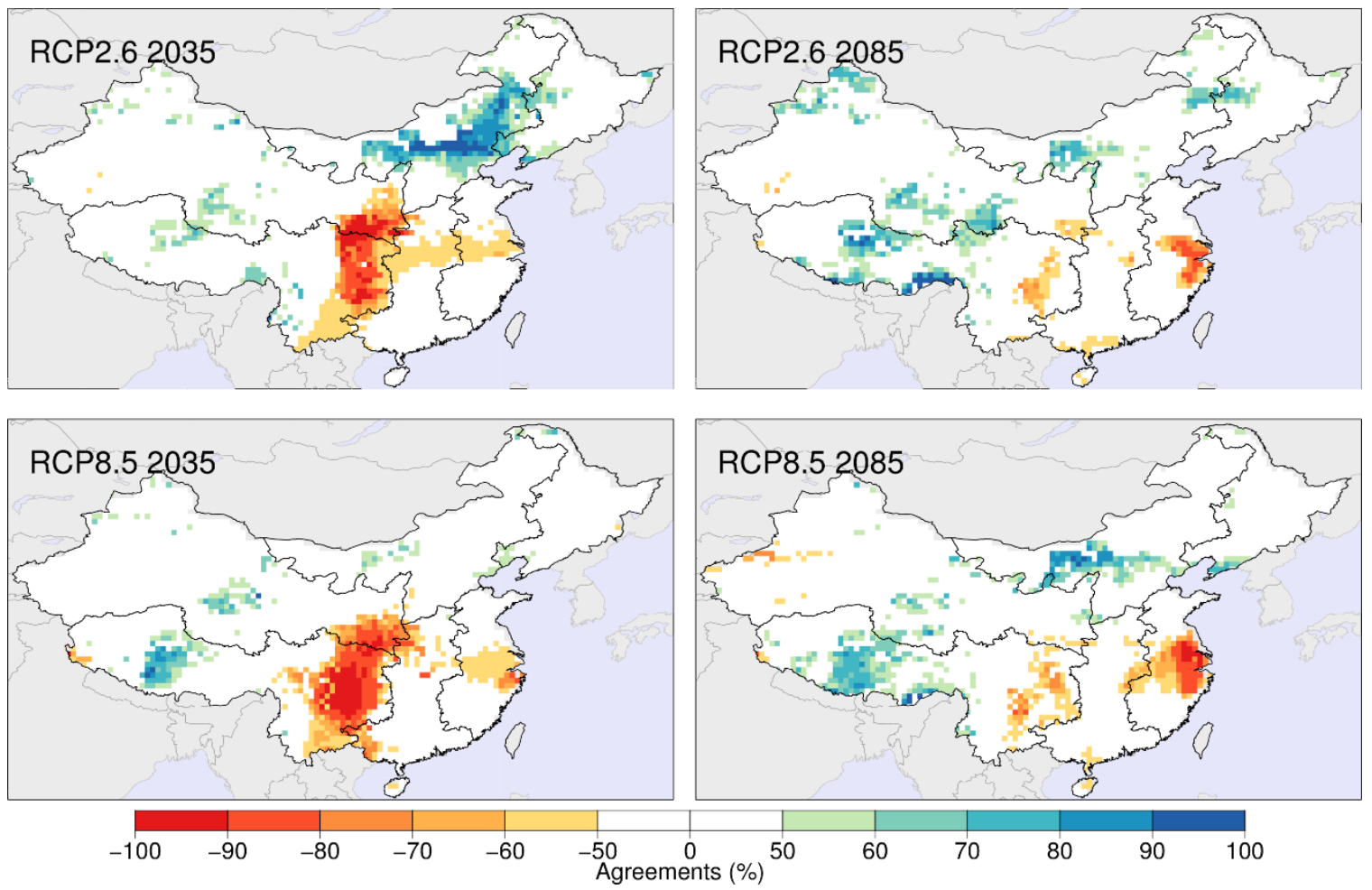

Figure S4. Agreements between relative GHP changes across the ensemble of GCM-GHM combinations calculated as the difference of positive and negative fractions of total ensemble. 


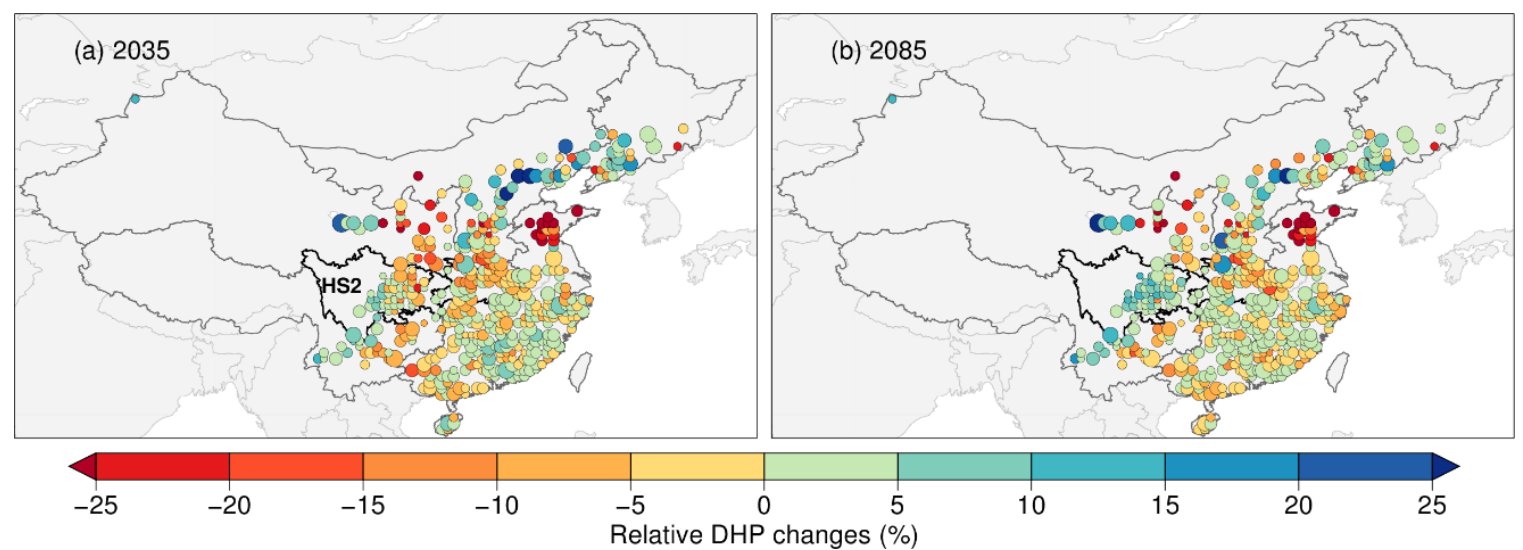

Figure S5. Relative DHP changes for each reservoir for 20202050 (2035) and 20702099 (2085) under

\section{RCP2.6.}

Black line depicts the hotspot region HS2, i.e. Sichuan (including Chongqing) and Hubei provinces. Circle size is determined according to the logarithm of reservoir storage capacity. 

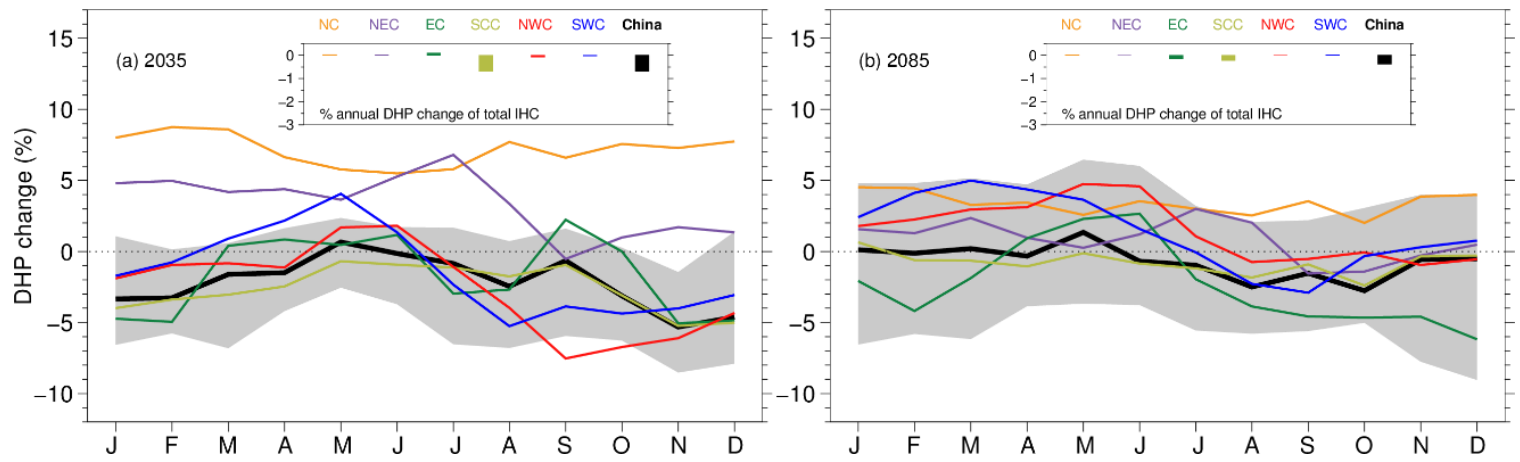

Figure S6. Relative DHP changes for regions of China for 20202050 (2035) and 20702099 (2085) under RCP2.6.

Lines show the ensemble medians across all GCM-GHM combinations; grey areas show the IQR of relative DHP changes of China; the inner plots show annual DHP changes of regions in terms of percentage of IHC. 

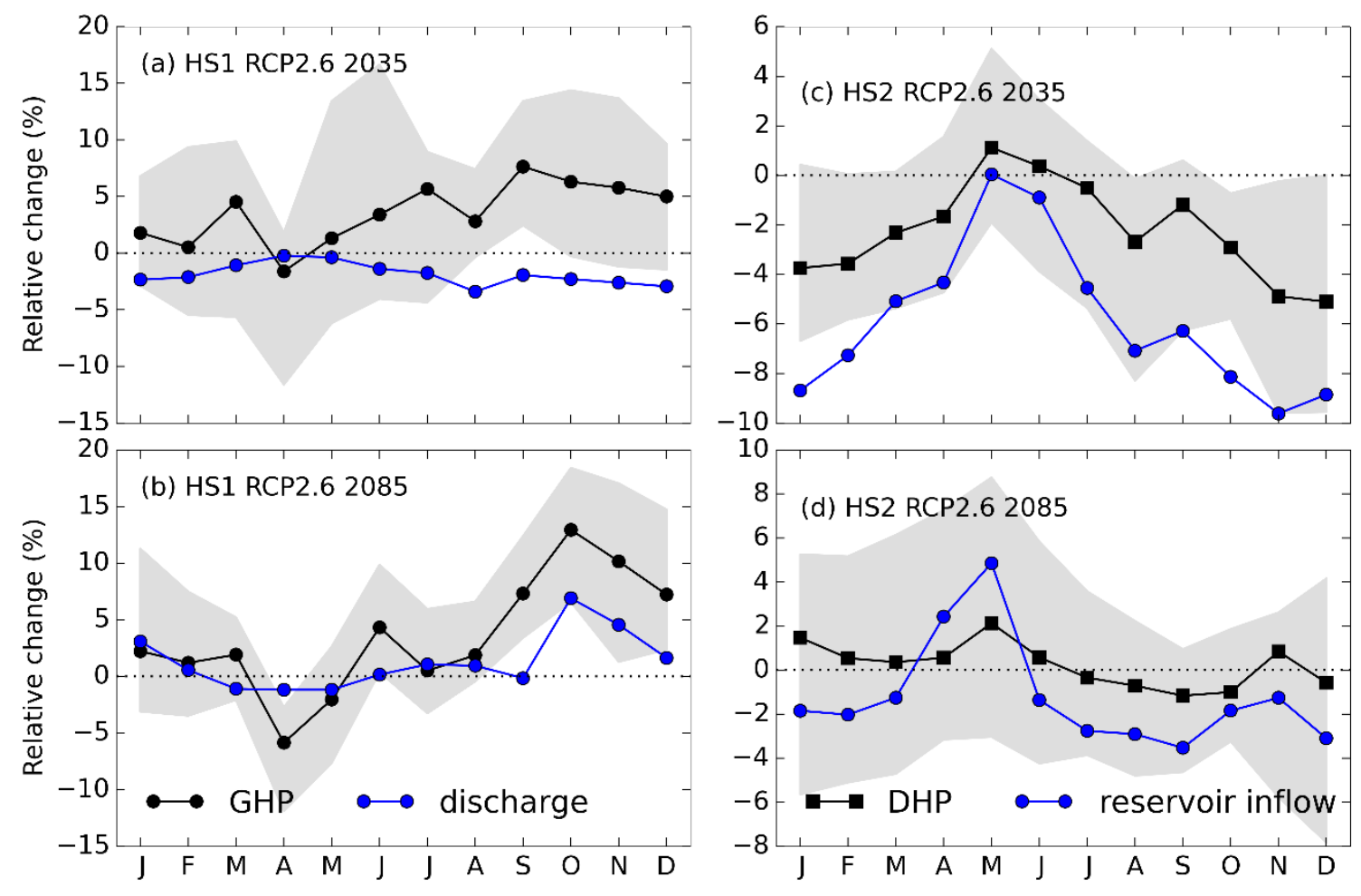

Figure S7. Relative changes in monthly GHPs (DHPs) and discharges (reservoir inflow) for hotspot regions for 20202050 (2035) and 20702099 (2085) under RCP2.6.

HS1: the hotspot region in Southwest China (see Figure 2); HS2: Sichuan and Hubei provinces (see Figure 6). Lines denote the ensemble medians across all GCM-GHM combinations and grey areas denote the IQRs across the ensemble of GCM-GHM combinations. 

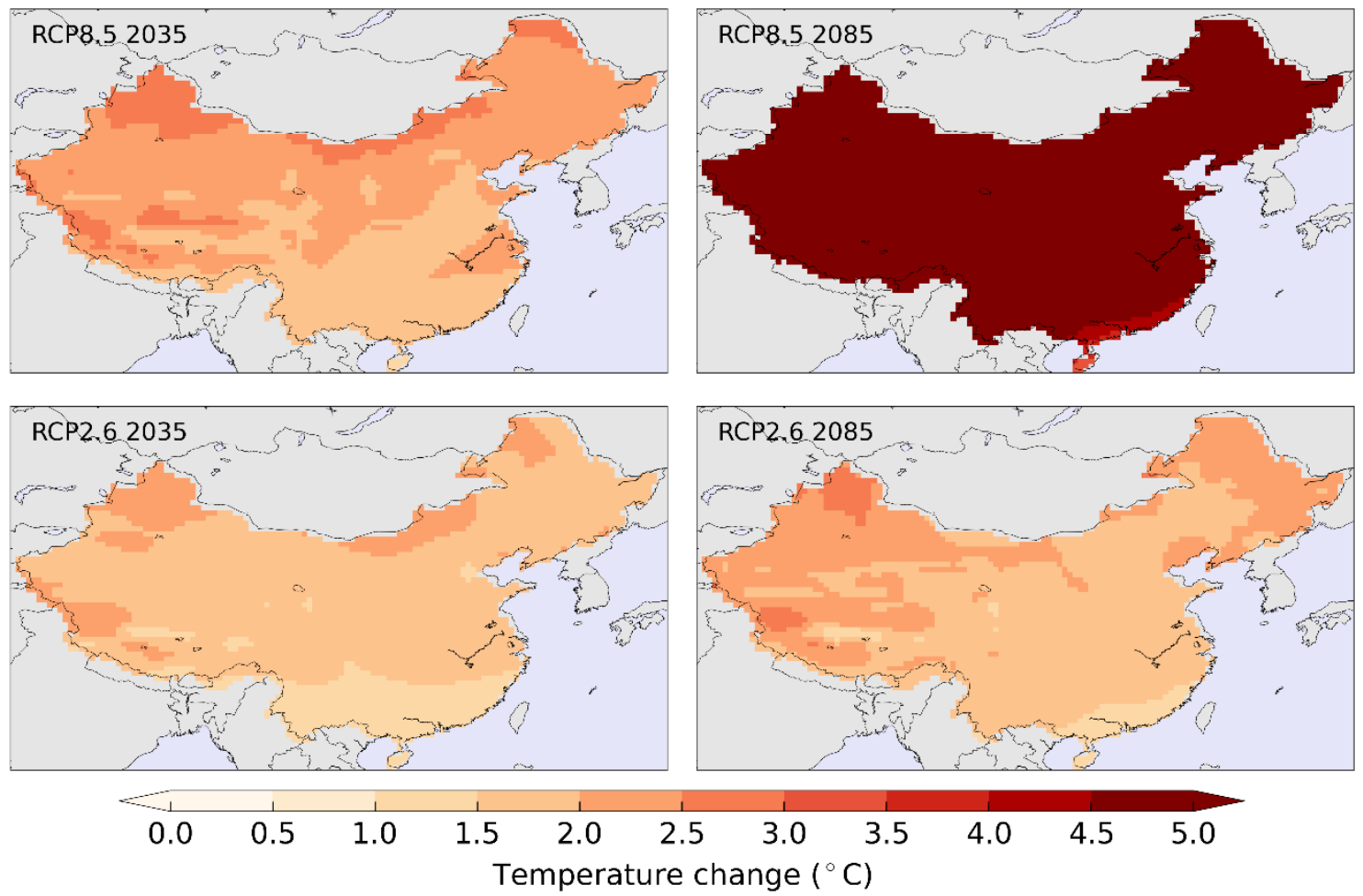

Figure S8. Medians of annual mean temperature changes in China in 2035 and 2085 compared to the historical period (1971 2000) across the five GCMs. 

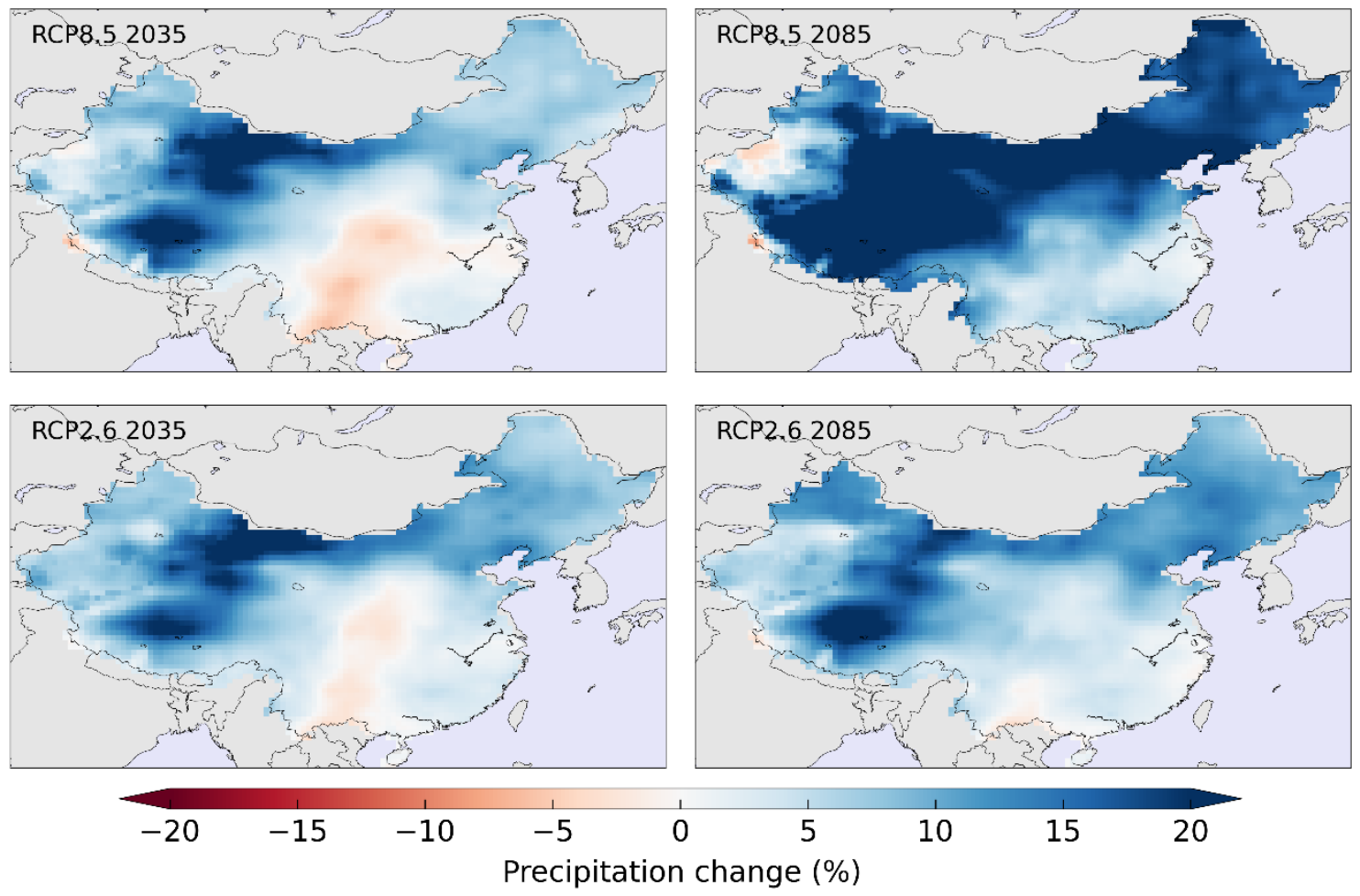

Figure S9. Medians of relative annual precipitation changes in China in 2035 and 2085 compared to the historical period (1971 2000) across the five GCMs. 

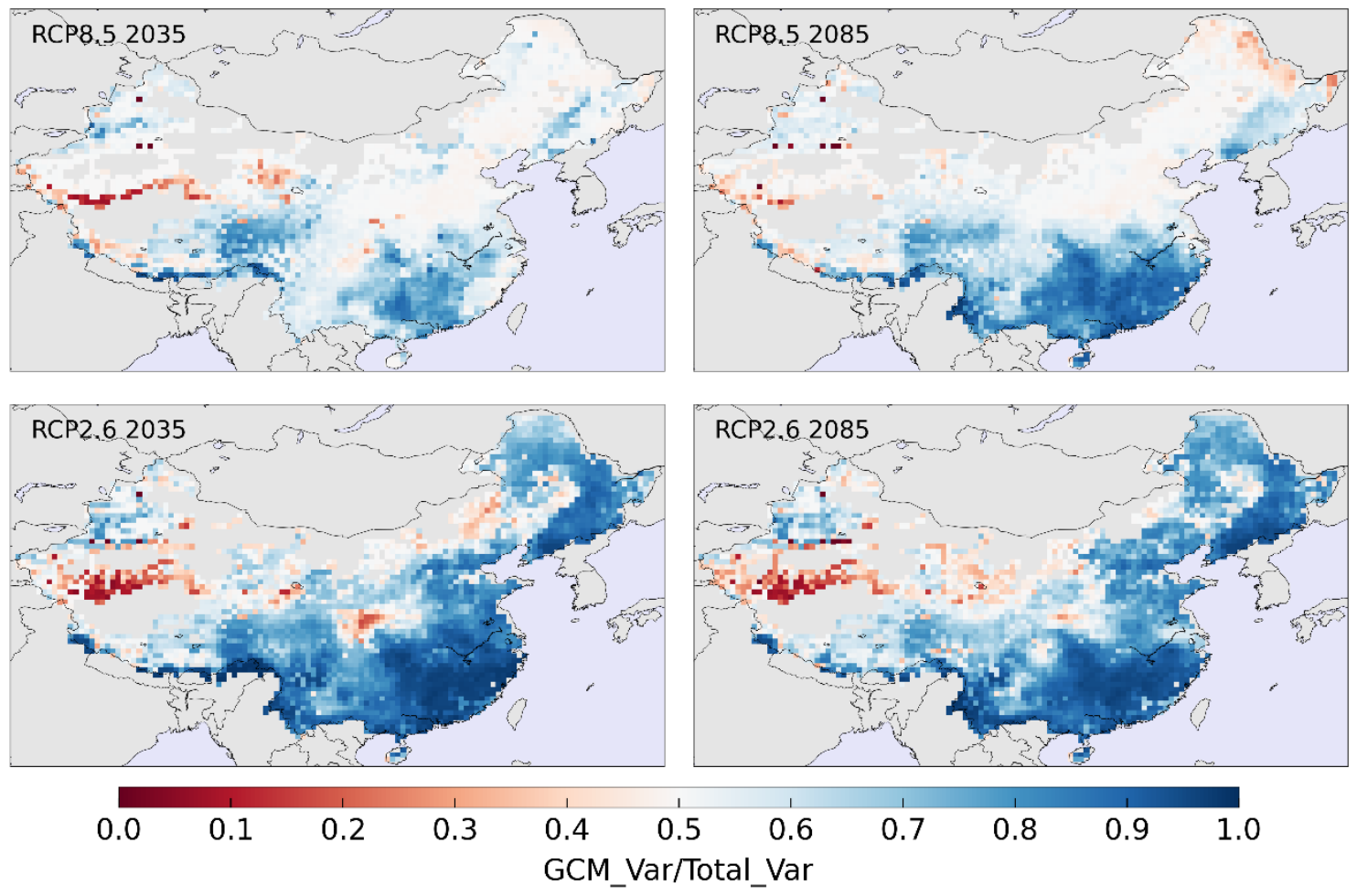

Figure S10. The ratio of GCM variance to total variance across all GCMs and GHMs.

GCM variance is computed across all GCMs for each GHM individually and then averaged over all GHMs, vice versa for GHM variance. In blue (red) areas, GCM (GHM) variance predominates. 

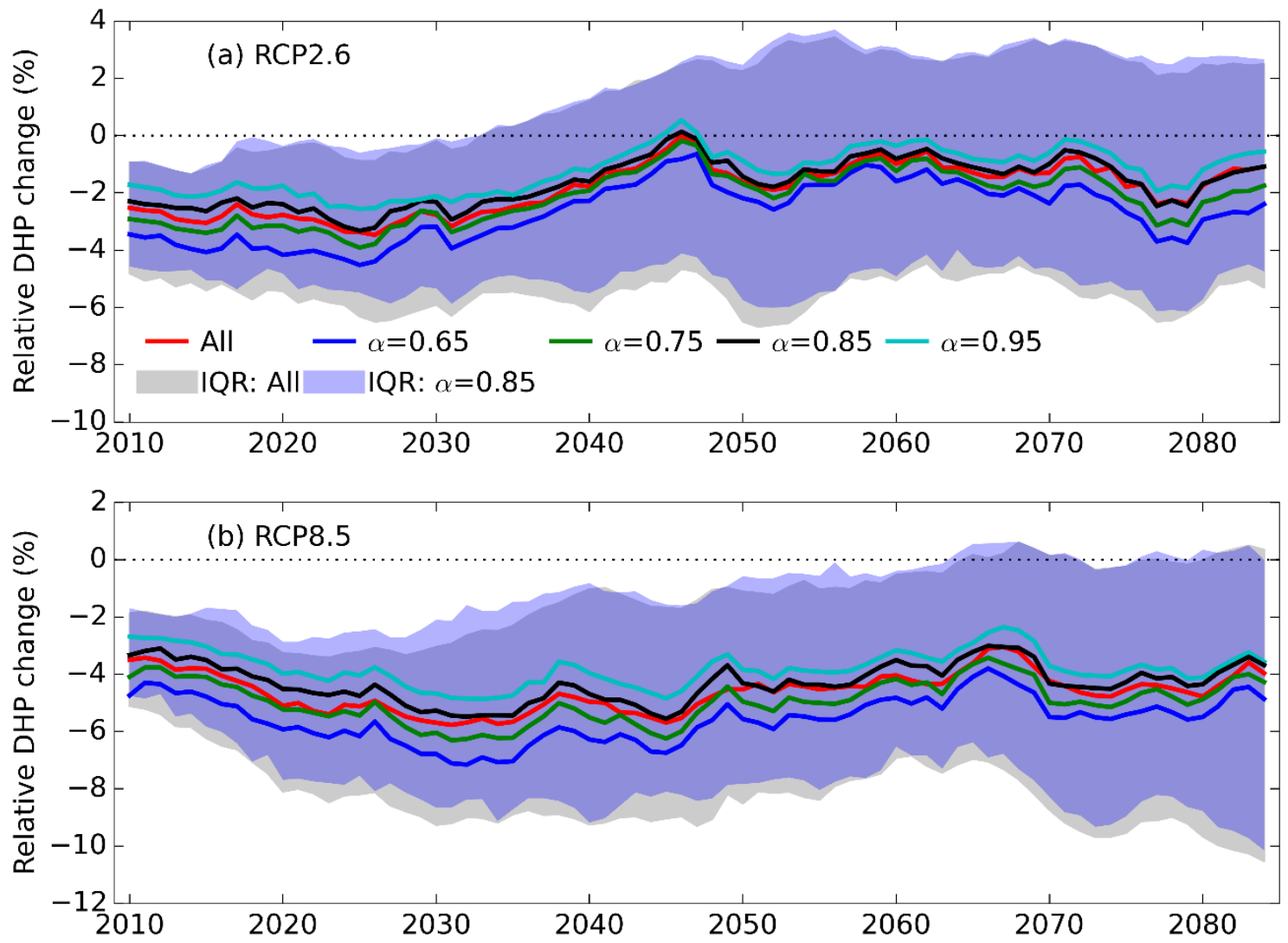

Figure S11. Medians of relative changes in the DHPs of present reservoirs in China over the 2010-2084 period under RCP2.6 (a) and RCP8.5 (b) for different $\alpha$ values.

To test the sensitivity of DHP to $\alpha$ values, several experiments with different $\alpha(=0.65,0.75,0.85,0.95)$ are carried out. Color lines show the medians of DHP for different $\alpha$ values. The black line shows the DHP in present study with $\alpha=0.85$. The gray area shows the range of $25^{\text {th }}$ and $75^{\text {th }}$ from the ensemble of GCMGHM combinations for all $\alpha$ values, while the light blue area shows the range of $25^{\text {th }}$ and $75^{\text {th }}$ from the ensemble of GCM-GHM combinations for $\alpha=0.85$. 

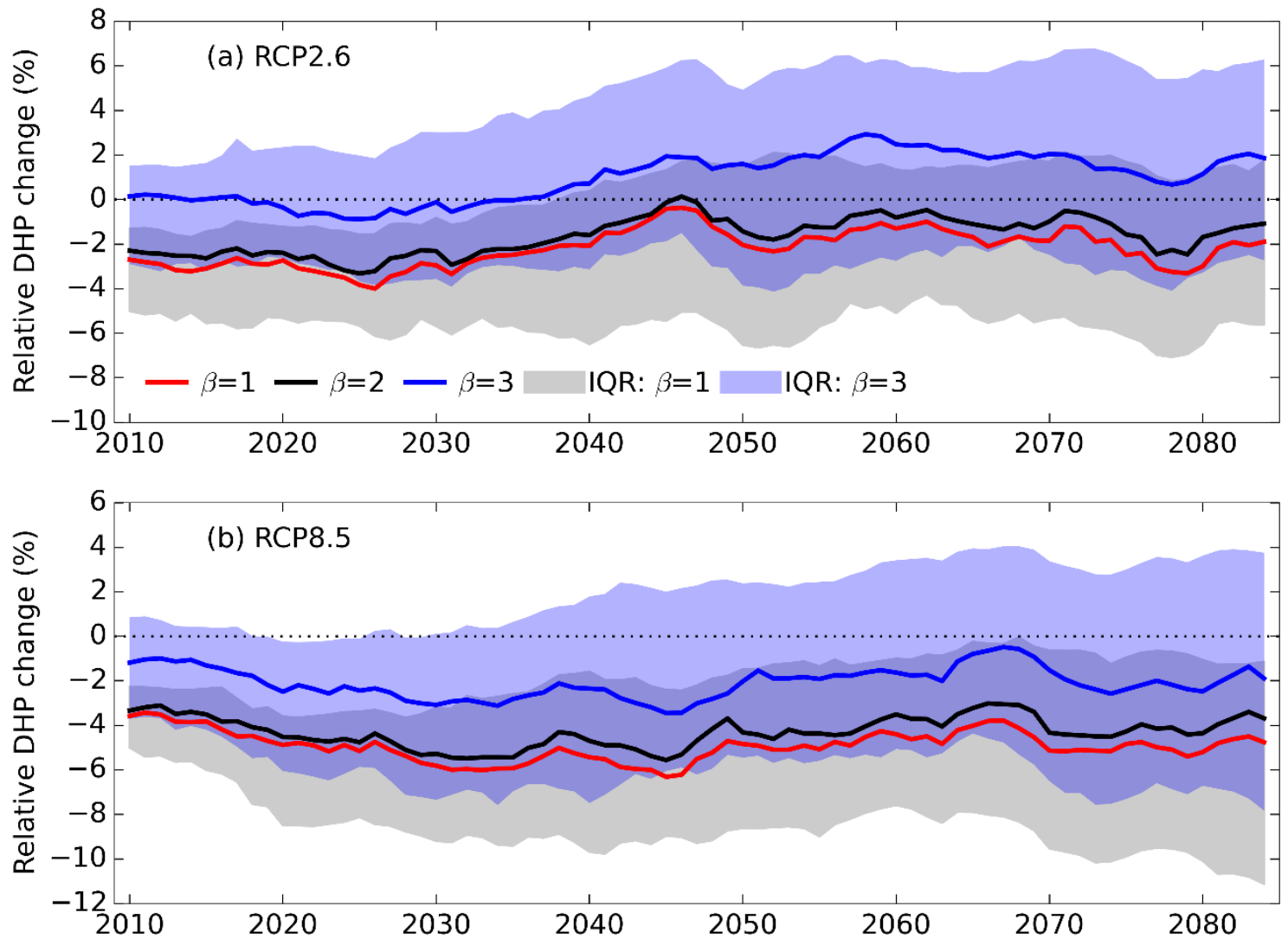

Figure S12. Medians of relative changes in the DHPs of present reservoirs in China over the 2010-2084 period under RCP2.6 (a) and RCP8.5 (b) for different $\beta$ values.

Two experiments with different exponents of $\left(c / K_{c}\right) \beta$ (see Equation 1) are carried out. Color lines show the medians of DHP for different $\beta$ values. The black line shows the DHP in present study with $\beta=2$ (used in this study). The gray area shows the range of $25^{\text {th }}$ and $75^{\text {th }}$ from the ensemble of GCM-GHM combinations for $\beta=1$, while the light blue area shows the range of $25^{\text {th }}$ and $75^{\text {th }}$ from the ensemble of GCM-GHM combinations for $\beta=2$. 

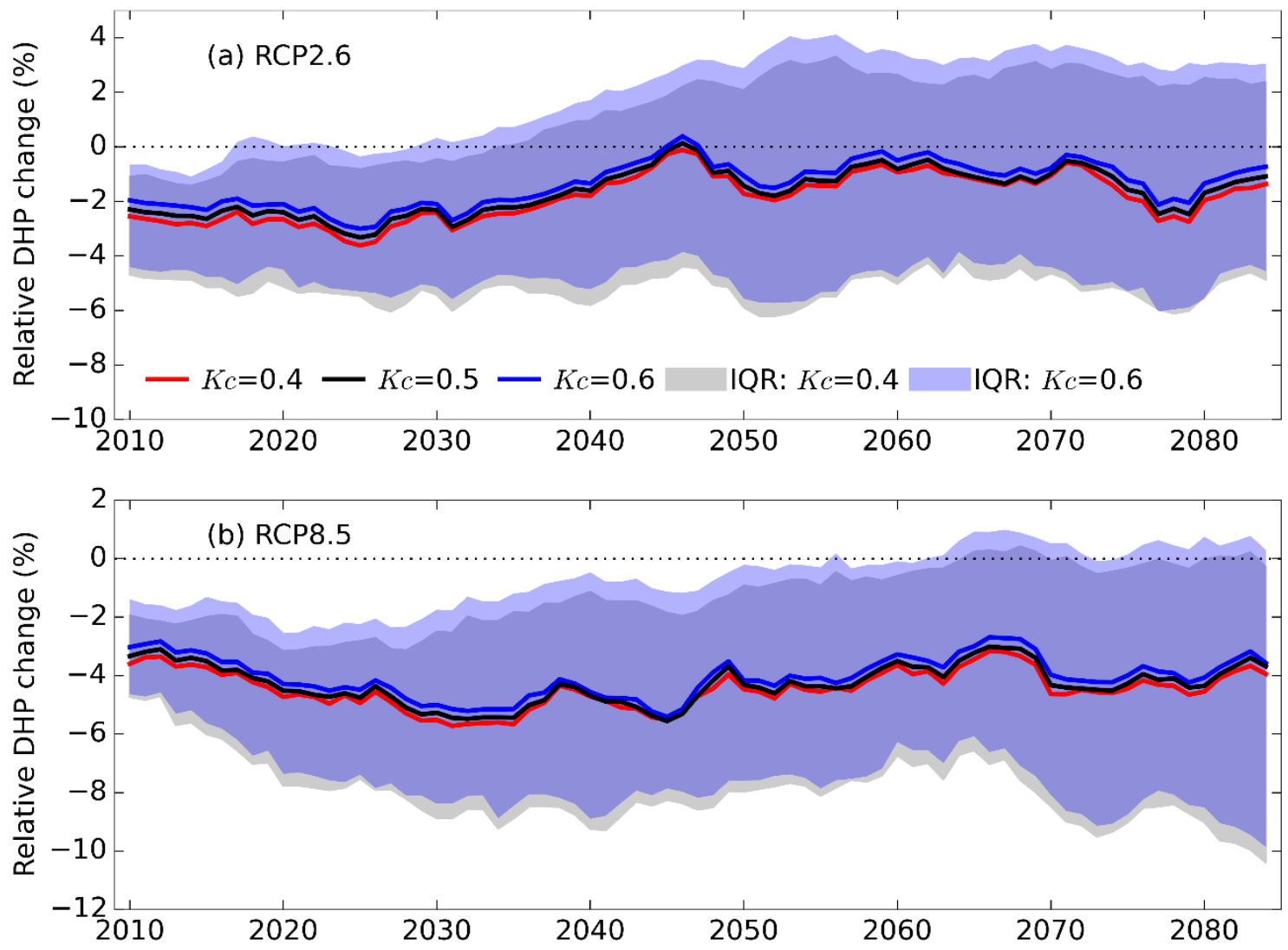

Figure S13. Medians of relative changes in the DHPs of present reservoirs in China over the 2010-2084 period under RCP2.6 (a) and RCP8.5 (b) for different $K_{c}$ values.

Two experiments with different $c$ criterions ( $K_{c}$, see Equation 1) are carried out. Color lines show the medians of DHP for different criterions. The black line shows the DHP in present study with $K_{c}=0.5$ (used in this study). The gray area shows the range of $25^{\text {th }}$ and $75^{\text {th }}$ from the ensemble of GCM-GHM combinations for $K_{c}=0.4$, while the light blue area shows the range of $25^{\text {th }}$ and $75^{\text {th }}$ from the ensemble of GCM-GHM combinations for $K_{c}=0.6$. 

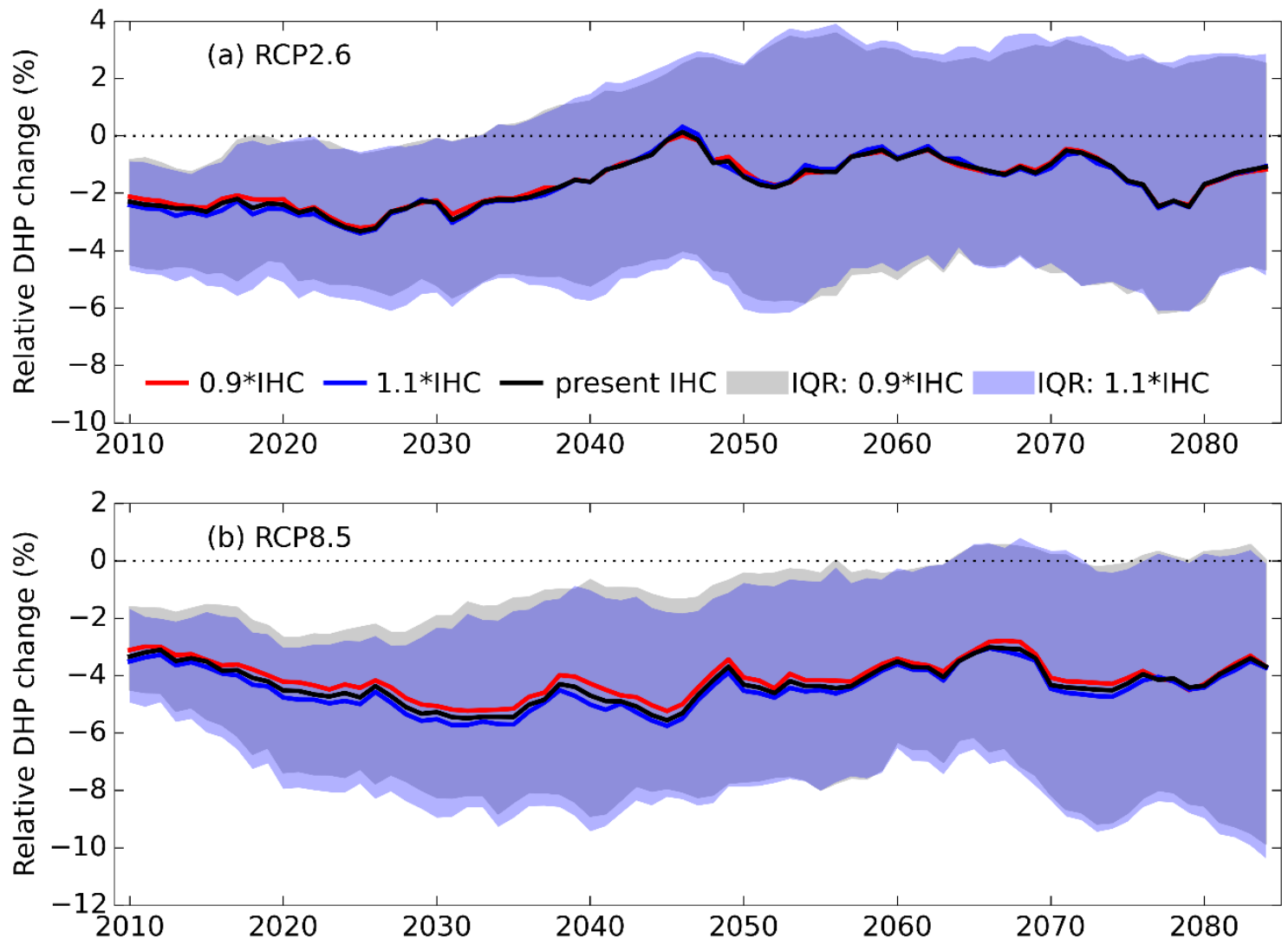

Figure S14. Medians of relative changes in the DHPs of present reservoirs in China over the 2010-2084 period under RCP2.6 (a) and RCP8.5 (b) for different IHCs.

To test the sensitivity of DHP to the IHC data, two experiments with IHC decrease by $10 \%(0.9 * \mathrm{IHC})$ and increase by $10 \%(1.1 * \mathrm{IHC})$, respectively, are carried out. Color lines show the medians of DHP for different IHC. The black line shows the DHP in present study with present IHC. The gray area shows the range of $25^{\text {th }}$ and $75^{\text {th }}$ from the ensemble of GCM-GHM combinations for $0.9^{*} \mathrm{IHC}$, while the light blue area shows the range of $25^{\text {th }}$ and $75^{\text {th }}$ from the ensemble of GCM-GHM combinations for $1.1^{*}$ IHC. 